\title{
OBSERVATIONS TO QUANTIFY AIR-SEA FLUXES AND THEIR ROLE IN CLIMATE VARIABILITY AND PREDICTABILITY
}

\author{
Christopher W. Fairall $^{(1)}$, Bernard Barnier ${ }^{(2)}$, David I. Berry ${ }^{(3)}$, Mark A. Bourassa ${ }^{(4)}$, E. Frank Bradley ${ }^{(5)}$, \\ Carol Anne Clayson ${ }^{(6)}$, Gerrit de Leeuw ${ }^{(7)}$, William M. Drennan ${ }^{(8)}$, Sarah T. Gille ${ }^{(9)}$, Sergey K. Gulev ${ }^{(10)}$, \\ Elizabeth C. Kent ${ }^{(3)}$, Wade R. McGillis ${ }^{(11)}$, Graham D. Quartly ${ }^{(3)}$, Vladimir Ryabinin ${ }^{(12)}$, Shawn R. Smith ${ }^{(4)}$, \\ Robert A. Weller ${ }^{(13)}$, Margaret J. Yelland ${ }^{(3)}$, Huai-Min Zhang ${ }^{(14)}$ \\ (1) NOAA/ESRL/PSD (National Oceanic and Atmospheric Administration/Earth System Research Laboratory/Physical \\ Sciences Division), R/PSD3, 325 Broadway, Boulder, CO 80305-3328, USA, Email: Chris.Fairall@noaa.gov \\ (2) LEGI (Laboratoire des Écoulements Géophysiques et Industriels), Domaine Universitaire, BP 53, 38041 Grenoble \\ Cedex 9, France, Email: bernard.barnier@legi.grenoble-inp.fr \\ ${ }^{(3)}$ National Oceanography Centre, Waterfront Campus, European Way, Southampton SO14 3ZH, United Kingdom, \\ Email:1yb@noc.soton.ac.uk, eck@noc.soton.ac.uk, gdq@noc.soton.ac.uk,mjy@noc.soton.ac.uk \\ (4) Center for Ocean-Atmospheric Prediction Studies, Florida State University, 2035 E. Paul Dirac Dr., \\ 200 RM Johnson Bldg., Tallahassee, FL 32306-2840, USA, Emails: bourassa@ coaps.fsu.edu, smith@coaps.fsu.edu

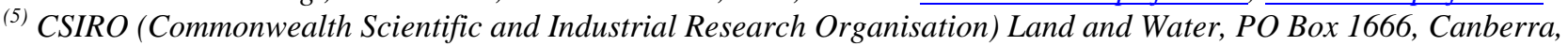 \\ ACT 2601, Australia, Email: Frank.Bradley@csiro.au \\ ${ }^{(6)}$ Department of Meteorology, 404 Love Building, Florida State University, Tallahassee, FL 32306, USA, \\ Email: cclayson@fsu.edu \\ (7) Finnish Meteorological Institute, Erik Palmenin Aukio 1, P.O. Box 503, FI-00101 Helsinki, Finland, \\ Email: gerrit.leeuw@fmi.fi \\ ${ }^{(8)}$ University of Miami, RSMAS (Rosenstiel School of Marine and Atmospheric Science), 4600 Rickenbacker Causeway, \\ Miami, FL 3314-1098, USA, Email: wdrennan@ rsmas.miami.edu \\ (9) Scripps Institution of Oceanography, 9500 Gilman Dr., La Jolla, CA 92093-0230, USA, Email: sgille@ucsd.edu \\ ${ }^{(10)}$ P.P. Shirshov Institute of Oceanology, RAS (Russian Academy of Sciences), 36 Nakhimovsky ave, \\ 117858 Moscow Russia, Email: gul@sail.msk.ru \\ ${ }^{(11)}$ Geochemistry, Lamont Doherty Earth Observatory Campus, Columbia University, Palisades, NY 10964, USA, \\ Email: Wade.McGillis@columbia.edu \\ (12) Joint Planning Staff for WCRP (World Climate Research Programme), WMO (World Meteorological Organization) \\ Secretariat, 7bis, Avenue de la Paix, CP 2300, Geneva 2, CH-1211, Switzerland, Email: VRyabinin@wmo.int \\ ${ }^{(13)}$ Woods Hole Oceanographic Institution, Mailstop 29, Woods Hole, MA 02543, USA, Email: rweller@whoi.edu \\ ${ }^{(14)}$ NOAA (National Oceanic and Atmospheric Administration) National Climatic Data Center, 151 Patton Ave.,
} Asheville, NC 28801, USA, Email: Huai-min.Zhang@noaa.gov

\section{ABSTRACT}

Flux products quantifying exchanges between ocean and atmosphere are needed for forcing models, understanding ocean dynamics, investigating the ocean's role in climate, and assessing coupled models. Research experiments are essential to improve flux parameterizations, and longer research deployments are required to sample rare events. Urgently needed technological improvements include longer battery life, more robust sensors and improvement of sensors for humidity, precipitation and direct gas and particle fluxes. A range of different flux products are needed, incorporating data from ships, satellites and models in different combinations and using different methods. All products must be characterized with uncertainty estimates. Dataset validation requires high quality observations from ocean flux reference sites and from ships. The continued development of flux products from satellites provides much-needed sampling. Continual intercomparisons among products and with high quality observations will lead to improved flux datasets, while improvements to the flux data management system
\end{abstract}

would facilitate these intercomparisons.

\section{INTRODUCTION}

OceanObs'99 [1] envisaged an air-sea flux observing system with research campaigns to improve flux parameterizations and an expansion of direct and autonomous flux measurements. The requirement for flux data with a coverage and resolution which conventional data sources could not supply was already apparent. The in situ flux observing system requires contributions from the Global Ocean Observing System (GOOS) and an ongoing partnership with Numerical Weather Predication (NWP) and climate modeling activities, remote sensing, and in situ observationalists. Progress since OceanObs'99 includes the deployment of flux reference buoys, development of packages for routine direct measurements of turbulent fluxes, the use of in situ data to validate NWP fluxes, the development of satellite-derived and blended flux products, and specialized validation activities. Concurrently the World Climate Research Program (WCRP)/Scientific Committee for Ocean Research (SCOR) Working 
Group on Air-Sea Fluxes (WGASF) undertook a comprehensive review of the status of surface flux measurement, parameterization, data products and requirements [2].

This paper, coordinated by the WCRP Working Group on Surface Fluxes, considers mainly the physical fluxes, the turbulent fluxes of sensible and latent heat; longwave and shortwave radiation, evaporation, precipitation and momentum. We also discuss progress in the measurement of fluxes of trace gases and aerosols. High-latitude air-sea and air-sea-ice fluxes are discussed elsewhere [3].

We focus on requirements for measurements of ocean surface fluxes and flux-related variables necessary for observing and predicting the changing climate. Uncertainty in the air-sea exchanges of heat, freshwater, carbon and other properties constrains our ability to understand and model our changing climate. Flux products are required for forcing ocean models, understanding ocean dynamics, investigating the forcing of variability by the atmosphere and ocean, understanding the ocean's role in climate variability and change, and assessing the realism of data-assimilative ocean models and coupled ocean-atmosphere models used for predictions from weather to climate time scales.

Direct flux measurements are scarce and cannot be used to generate global flux datasets. Rather the surface fluxes are parameterized in terms of bulk meteorological estimates of the surface atmospheric and oceanic states. These parameterizations, used to compute fluxes from observed variables as well as those used in NWP and reanalyses, also require continuous improvement. An effective flux observing strategy must include analysis activities to provide intercomparison of flux-related variables from different sources, improvements to the accuracy of parameterizations and development of flux products to satisfy the requirements of climate prediction.

\section{ACCURACY AND RESOLUTION REQUIREMENTS FOR SURFACE FLUXES}

The accepted benchmark for surface net heat flux accuracy is $\pm 10 \mathrm{Wm}^{-2}$ over monthly to seasonal time scales [4, 5 and 6], implying determination of individual components of the net heat flux to a few $\mathrm{Wm}^{-2}$. Where turbulent fluxes are parameterized this sets limits on the mean bias of the input observations [7] of $0.2 \mathrm{~K}$ for air and sea temperatures, $0.3 \mathrm{~g} \mathrm{~kg}^{-1}$ for humidity and a few tenths $\mathrm{ms}^{-1}$ for wind speed [8]. If gridded flux products are to be calculated to this accuracy there are further requirements for adequate sampling and on the random uncertainty of individual measurements [9].
Accuracy requirements for freshwater flux (Evaporation - Precipitation, E-P) are hard to estimate. The background uncertainty among E-P products over the ocean has been estimated at 120-250 mm year ${ }^{-1}$ [10 and 11], mostly attributable to uncertainty in the precipitation. The lack of open ocean reference data for comparison makes all precipitation estimates very uncertain. Knowledge of surface salinity to an accuracy of 0.1 psu should allow constraint of the ocean freshwater budget to $100 \mathrm{~mm}_{\text {year }}{ }^{-1}$ [12].

Accuracy and resolution requirements are application dependent. Ocean modeling requires high-resolution forcing: it is expected that global model resolutions of $1 / 8^{\circ}$ to $1 / 12^{\circ}$ will become widely used requiring forcing at $5-10 \mathrm{~km}$ and 30 to 60 minutes. The desired accuracy of better than $10 \mathrm{Wm}^{-2}$ is only possible on much longer scales. Errors in fluxes increase with interpolation and error characteristics become non-homogeneous if smoothing is too small relative to the sampling [13].

Biases in fluxes due to the parameterizations used in atmospheric reanalyses greater than $40 \mathrm{Wm}^{-2}$ are common ([14 and 15] Fig. 1). Short-term integrations are more sensitive to random errors than biases. Spectral analysis shows that despite operational NWP grid spacing that is similar to the desired scale, these highresolution requirements are not yet met [16].

For regional applications an accurate representation of synoptic and sub-synoptic wind stress variability is required [17, 18 and 19]. For the forecasting of particularly sensitive ocean phenomena, such as ENSO (El Niño/Southern Oscillation) [5], uncertainties in wind shear due to surface currents [17, 20, 21 and 22] and waves [23] may be important. Available flux products produce insufficient ocean mixing due to poor representation of diurnal variations [24] and small scale variability such as at atmospheric fronts [25]. Ocean wind-wave modeling requires highly accurate wind vectors with high space-time resolution and adequate representation of ageostrophic patterns [26].

Climate scale integrations aggregate errors over large time and space scales and are particularly sensitive to systematic biases, although random errors can be important where ocean circulation is forced locally (e.g. convection in the subpolar regions may require accuracy of local monthly net heat flux anomalies of 3-5 $\mathrm{Wm}^{-2}$ ). There are currently no products that meet these accuracy requirements.

Studies of climate change and decadal variability must resolve changes in the net heat flux of few $\mathrm{Wm}^{-2}$ per decade [27], well beyond the capabilities of current observing systems. These studies also require accurate estimation of ocean precipitation. 
a)
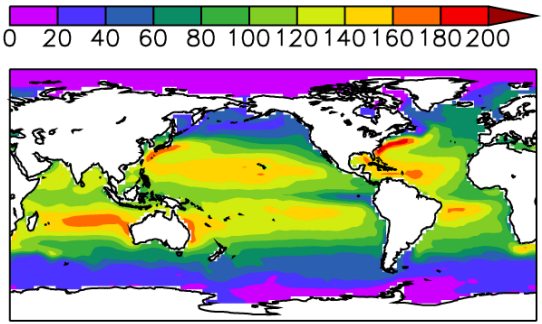

Mean latent heat flux $\left(\mathrm{Wm}^{-2}\right)$ from 3 datasets

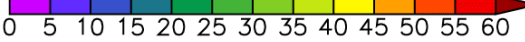

b)

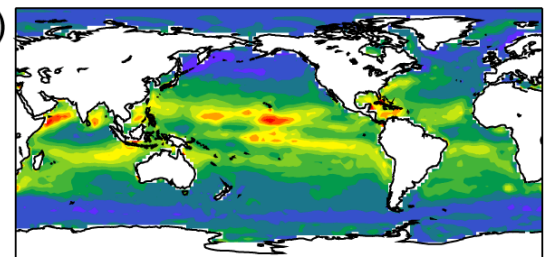

Range of latent heat flux difference $\left(\mathrm{Wm}^{-2}\right)$ for 1960-1969

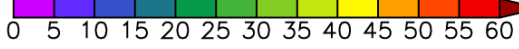

c)

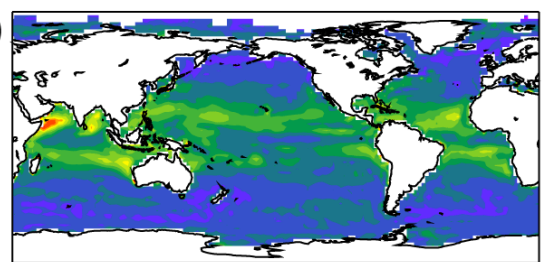

Range of latent heat flux difference $\left(\mathrm{Wm}^{-2}\right)$ for 1990-1999

d)

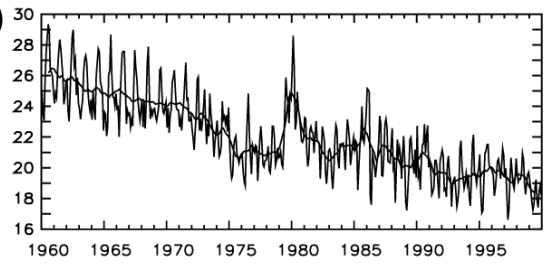

Global mean range of latent heat flux difference $\left(\mathrm{Wm}^{-2}\right)$

Figure 1: Monthly mean fluxes from NCEP, ERA-40 (ECMWF (European Centre for Medium-Range

Weather Forecasts) Re-analysis-40), and OAFlux

(Objectively Analyzed air-sea Fluxes). a) latent heat

flux averaged over 1960 to 1999; b) range across products in monthly-mean estimates from 1960 to 1969;

c) as b) for 1990 to 1999; d) time series of global average difference range (individual months and 12 month running mean).

\section{OBSERVING SYSTEMS FOR SURFACE FLUXES AND RELATED PARAMETERS}

The surface flux observing system uses instruments mounted on moorings, ships and satellites. The radiative and precipitation fluxes are usually measured directly; in a few cases the turbulent fluxes are also obtained directly by fast-response covariance instruments. More commonly fluxes are computed from meteorological variables using bulk flux algorithms with roughly half the accuracy of directly-measured fluxes. The in situ instruments are described in detail [28]. Costs for high- quality bulk meteorological and direct flux packages have declined since the detailed assessment of [1]. Each of the systems described has its advantages and limitations. Table 1 summarizes the sources of each type of in situ measurement and Fig. 2 indicates the period of availability of all types of measurement.

\subsection{OceanSITES}

A subset of the OceanSITES global array [29] provides high quality surface meteorological measurements for bulk formula flux estimation and sensors for precipitation, solar and infrared radiation. OceanSITES (OCEAN Sustained Interdisciplinary Time series Environment observation System) data can help diagnose random errors and biases in model, in situ and satellite-based flux fields. Figure 3 summarizes the sites proposed at OceanObs' 99 , the present surface moorings, and the sites planned for the near future. It is clear that distributed coverage across each of the ocean basins has yet to be achieved. Technology improvements will be required to expand the range of measurements to include direct fluxes and to expand the geographical range.

\subsection{Operational Buoys}

International cooperation now maintains tropical moorings in the Pacific (TAO/TRITON (Tropical Atmosphere Ocean/Triangle Trans-Ocean Buoy Network), [30]), Indian (RAMA (Moored Array for African-Asian-Australian Monsoon Analysis and Prediction), [31]) and Atlantic Oceans (PIRATA (Prediction and Research Moored Array in the Atlantic), [32]). All surface moorings carry basic meteorological sensors to support determination of the air-sea fluxes of heat, freshwater, and momentum via the bulk formulae methods; many also carry barometric pressure, rain, and solar flux sensors. Efforts continue to utilize both coastal and deep water weather buoys and add sensors for bulk formulae estimation of fluxes. Long servicing intervals, vandalism and the wave environment of some coastal locations present challenges to this effort.

\subsection{Voluntary Observing Ships (VOS)}

The multi-decadal record from VOS (Voluntary Observing Ships) contains parameters from which all components of the heat budget and precipitation can be computed [33]. OceanObs'99 proposed an enhanced VOS subset equipped with improved sensors should be developed to diagnose bias and improve data quality. However, VOS automation has typically been driven by the requirements of data assimilation for NWP, which has led to a reduction in the range of parameters reported including a decrease in visual observations of waves, weather and cloud. Data quality has however typically improved. Recently the number of VOS reports has declined dramatically [34]. Uncertainties in net heat flux in VOS-based datasets [9] have increased by over $30 \%$ since the 1980 s. In the relatively well- 
sampled region $20^{\circ} \mathrm{N}-60^{\circ} \mathrm{N}$ the uncertainty has increased by over $50 \%$. A minority of regions are better sampled now than in the 1980s, as resources have been targeted in data sparse regions.

\subsection{Research Vessels (RVs)}

Historically, flux observations on RVs have only been collected during dedicated science cruises but following OceanObs'99 routine underway data collection efforts have begun with the establishment of the SAMOS (Shipboard Automated Meteorological and Oceanographic System) initiative [35]. RVs provide a versatile platform for flux measurement including gases and particles. Advantages include ample power and mounting locations for multiple sensors allowing both direct and bulk flux observations, onboard technical support, and capacity to collect and store observations at high temporal frequency $(>1 \mathrm{~Hz})$. Limitations of all ship measurements include the effect of ship heating and airflow distortion (e.g. [36, 37 and 38]); however, careful sensor sitting and duplicate instrumentation can ameliorate this [8].

\subsection{Remotely sensed data}

Turbulent fluxes are estimated from remotely sensed atmospheric parameters using bulk parameterizations [39, 40 and 41]. The most mature satellite algorithms are for SST (Sea Surface Temperature) [42] and vector and scalar wind speeds and stress [43]. The estimation of near-surface humidity and temperature using neural network retrievals in a variety of atmospheric conditions shows important improvements [44 and 45]. Needed improvements include improved sampling of surface vector winds, especially at high wind speeds and rain conditions, higher spatial resolution, especially coastally, and improved temporal coverage by both passive and active microwave sensors.

\begin{tabular}{|c|c|c|c|}
\hline Parameter & Source & Coverage & Applications \\
\hline $\begin{array}{l}\text { Direct turbulent } \\
\text { fluxes including of } \\
\text { gases and particles. } \\
\text { Environmental } \\
\text { information, e.g. sea } \\
\text { state, cloud, } \\
\text { subsurface } \\
\text { temperature. }\end{array}$ & $\begin{array}{l}\text { Research campaigns on ships, fixed } \\
\text { platforms and buoys. Routinely on } \\
\text { some coastal platforms, OWS, and } \\
\text { possibly in future from OceanSITES, } \\
\text { Shipboard Automated Meteorological } \\
\text { and Oceanographic System (SAMOS) } \\
\text { Initiative and ships of opportunity (e.g. } \\
\text { VOSClim). }\end{array}$ & $\begin{array}{l}\text { Sparse in space and time. } \\
\text { Recent start of sustained } \\
\text { observations on limited } \\
\text { number platforms (e.g. } \\
\text { OWS) with planned } \\
\text { expansion (e.g. to } \\
\text { OceanSITES). }\end{array}$ & $\begin{array}{l}\text { Improved flux } \\
\text { parameterizations and } \\
\text { understanding of } \\
\text { processes and } \\
\text { variability. }\end{array}$ \\
\hline $\begin{array}{l}\text { Direct precipitation } \\
\text { and radiation. }\end{array}$ & $\begin{array}{l}\text { As direct fluxes but currently available } \\
\text { on some OceanSITES, SAMOS and } \\
\text { ships of opportunity. Some operational } \\
\text { moorings. }\end{array}$ & $\begin{array}{l}\text { As direct fluxes but some } \\
\text { observations available } \\
\text { since mid-90s (e.g. TAO). }\end{array}$ & $\begin{array}{l}\text { Satellite, NWP } \\
\text { intercomparisons and } \\
\text { validation. } \\
\text { Improved } \\
\text { parameterizations } \\
\text { based on visual } \\
\text { observations. }\end{array}$ \\
\hline $\begin{array}{l}\text { Mean meteorology } \\
\text { (air temperature, } \\
\text { wind speed and } \\
\text { direction, pressure, } \\
\text { humidity, SST) }\end{array}$ & $\begin{array}{l}\text { All sources above plus VOS \& } \\
\text { VOSClim. }\end{array}$ & $\begin{array}{l}\text { Long time-series, quasi- } \\
\text { global coverage (sparse in } \\
\text { southern hemisphere). }\end{array}$ & $\begin{array}{l}\text { Validation. } \\
\text { Gridded flux products. } \\
\text { Assimilated into NWP } \\
\text { and reanalysis. }\end{array}$ \\
\hline $\begin{array}{l}\text { Visual cloud and } \\
\text { weather observations }\end{array}$ & VOS \& VOSClim. & As for mean meteorology. & $\begin{array}{l}\text { Gridded radiative and } \\
\text { precipitation flux } \\
\text { products. }\end{array}$ \\
\hline
\end{tabular}

Table 1. In situ observing system components. 


\section{Sources of Flux Data}
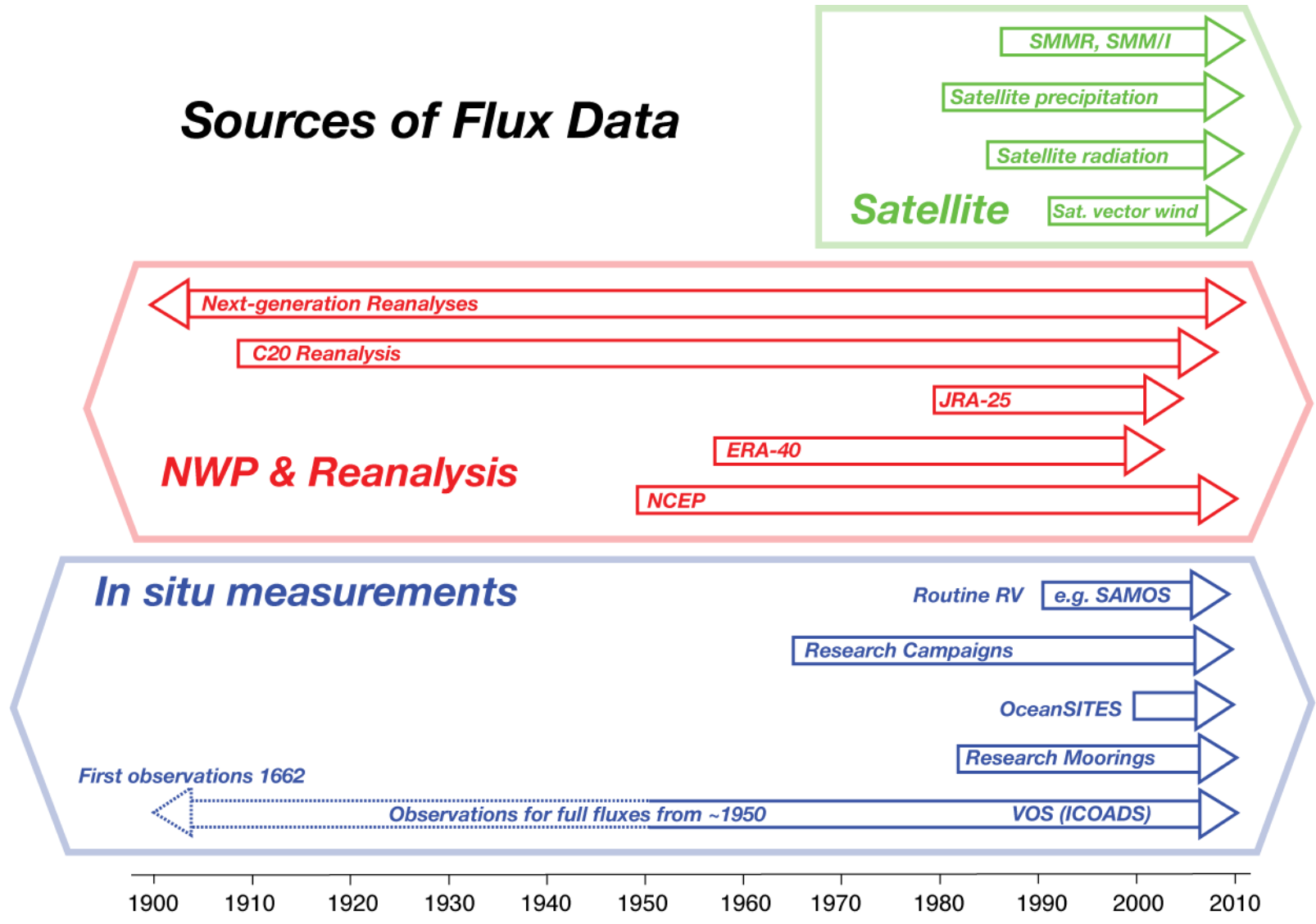

Figure 2: Timeline showing availability of surface flux and flux-related data.
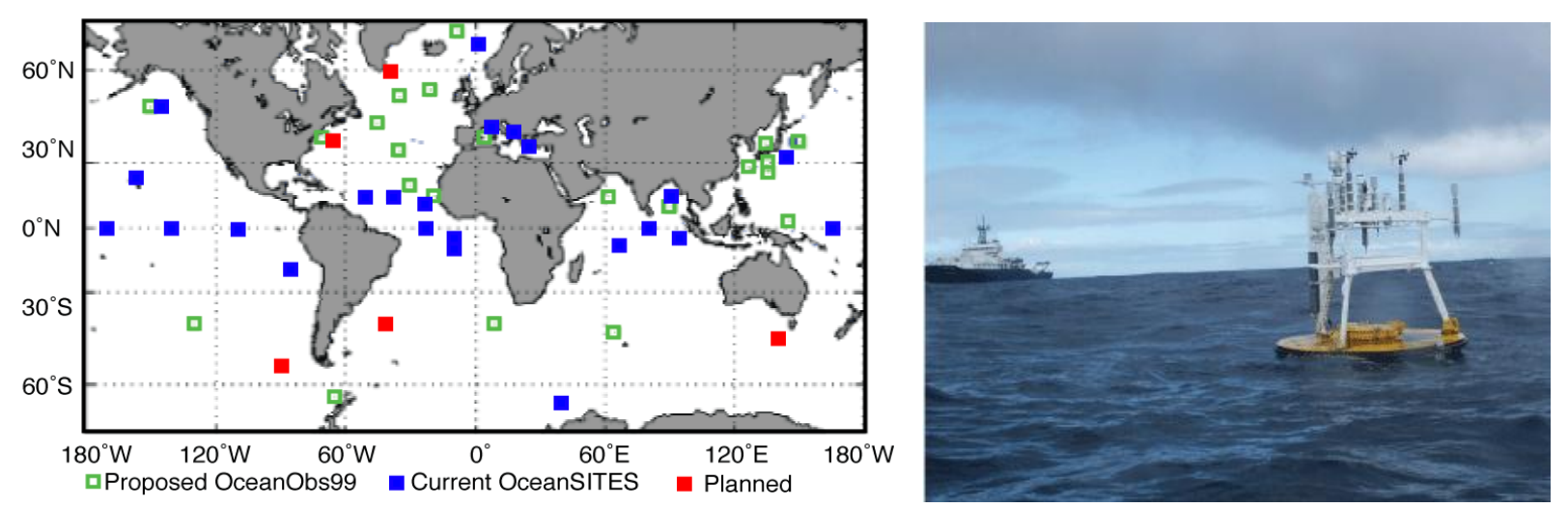

Figure 3: Global map of flux reference sites and Flux reference buoy off Chile with $R / V$ Roger Revelle nearby.

Satellite based estimates of surface radiative fluxes use measurements of top-of-the-atmosphere radiation and cloud measurements with radiative transfer models from a variety of polar-orbiting and geostationary satellites. Data are available from the polar orbiting Advanced Very High Resolution Radiometer (AVHRR) and TIROS Operational Vertical Sounder (TOVS) on NOAA (National Oceanic and Atmospheric Administration) satellites and the NASA (National Aeronautics and Space Administration) Moderate Resolution Imaging Spectroradiometer (MODIS) and
Geostationary Operational Environmental Satellites (GOES).

Precipitation is difficult to sample because of its patchiness, only remote sensing methods (surface-based radars and/or satellites) offer any spatial coverage at short time scales. Satellite sensors show sensitivity to rain (passive microwave) or to cloud parameters indirectly related to rainfall (IR (Infrared) sensors). There have been regular passive microwave observations since mid 1987, although with sensor footprints much larger than most active rain cells. IR 
measurements extend further back. Algorithms can err by more than a factor of two for instantaneous rainfall [46]; but long-term areal averages have better accuracy and consistency. Estimating rates for frozen forms of precipitation is particularly difficult. The Precipitation Radar on Tropical Rainfall Measuring Mission (TRMM) presently offers the most accurate precipitation estimates [47], but its coverage is limited to the tropics and the period since December 1997 and monthly sampling errors are significant.

\section{FLUX PRODUCTS}

\subsection{Gridded In situ Datasets}

Multi-decadal flux datasets have been based on VOS observations in the International Comprehensive OceanAtmosphere Dataset (ICOADS, [48, 49 and 50]). Recent advances provide datasets well-characterized with uncertainty estimates and with improved representation of variability and trends [9]. Problems with an imbalance in the global and regional heat budgets remain [2] reflecting uncertainties in parameterization, bias adjustment, and sampling errors. This has led to attempts to balance the heat budget using external constraints (e.g. [51]). The availability of uncertainty estimates means that research can be focused in regions with appropriate accuracy for the particular application.

\subsection{Satellite Data Products}

Satellites provide good quality estimates of surface stress and radiation for recent decades. However, sampling is irregular in space and time, resulting in spatially and temporally varying error characteristics [13] and irregular representation of fine synoptic scale variability.

Gridded surface sensible and latent heat flux products include GSSTF (Goddard Satellite-Based Surface Turbulent Fluxes) [52], J-OFURO (Japanese Ocean Flux Data sets with Use of Remote Sensing Observations) [53], HOAPS (Hamburg Ocean Atmosphere Parameters and Fluxes from Satellite Data) [39], and from IFREMER (French Research Institute for Exploitation of the Sea/Institut Français de Recherche pour l'Exploitation de la Mer) [40]. Comparisons by the SeaFlux project of these products with in situ direct flux measurements have shown their value [54]: uncertainties are generally less than $20 \mathrm{Wm}^{-2}$. Issues remain with retrievals of near-surface specific humidity and temperature and the combination of data from different satellites and sensors. Improved algorithms, as well as a careful selection of spectral bands on future sensors, should lead to further improvements.

The International Satellite Cloud Climatology Project (ISCCP, [55]) provides solar and IR radiative surface fluxes for the period 1983 to 2006 from GOES satellites. Quality declines near the poles and there are issues with matching boundaries between satellites. In stratocumulus regions low clouds may be poorly differentiated from mid clouds [56]. Accuracy is however better than for atmospheric reanalyses [57 and 58 ] with monthly regional accuracies within $15 \mathrm{~W} \mathrm{~m}^{-2}$. MODIS-derived satellite radiative fluxes from the CERES (Clouds and the Earth's Radiant Energy System) program [59 and 60] might offer potential advantages in accuracy, but have poorer sampling.

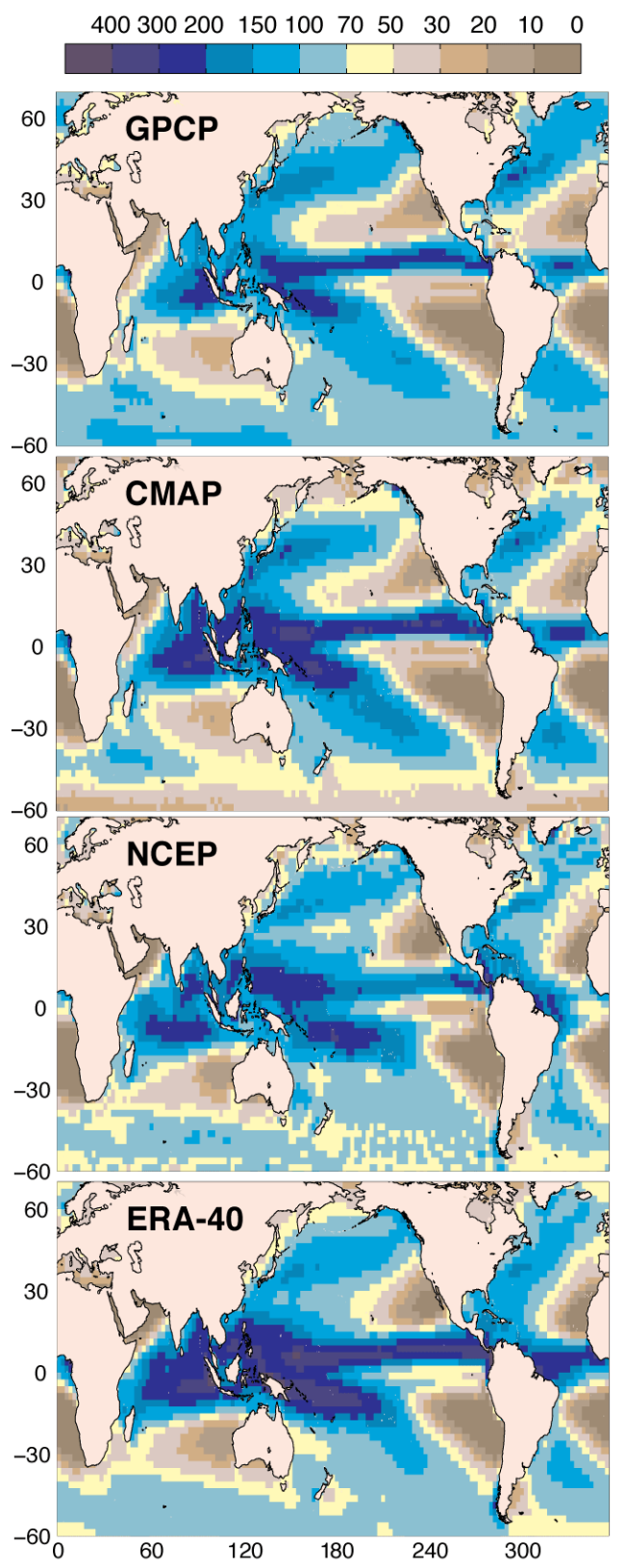

Figure 4: Global Ocean precipitation ( $\mathrm{mm} \mathrm{month}^{-1}$ ) averaged over 1979 to 2000 from GPCP, NCEP, CMAP and ERA-40.

Composite satellite-based precipitation products include CMAP (Climate Prediction Center (CPC) Merged Analysis of Precipitation) [61], GPCP (Global Precipitation Climatology Project) [62] and CMORPH (CPC MORPHing technique) [63]. There are 
differences between these products ([11 and 64, Fig. 4); reported accuracies are within $10 \%$ in the tropics and $15 \%$ in the mid-latitudes.

\subsection{Fluxes from NWP reanalyses and operational analyses}

Numerical models provide fluxes and meteorological parameters on a regular global grid. NWP models still have poor representation of some physical processes near the surface and do not adequately use available observational data. High quality in situ flux data are required for validation: the WCRP Surface Flux Analysis (SURFA) initiative [65] provides an infrastructure for comparisons.

Atmospheric reanalyses [66, 67, 68 and 69] have provided long-term flux datasets based on consistent model formulations including assimilation of atmospheric data. Although not high accuracy [2] reanalysis fluxes have been used in a wide range of research applications. Although reanalysis fluxes are affected by temporal changes in data assimilation input [70], they can be used for tentative estimates of longterm variability in surface fluxes [71]. Precipitation from atmospheric reanalyses can show unrealistic trends (ERA-40), or incorrect seasonal cycles [72] although reanalyses can reproduce the interannual changes associated with the North Atlantic Oscillation and ENSO [73]. A reanalysis assimilating only surface data will provide surface fluxes from 1908 onwards [74]. The next generation of reanalyses [75] may provide improved surface flux estimates.

\subsection{Blended and hybrid turbulent heat flux products}

Global flux products using multiple input data sources (e.g. [76, 77 and 64]) are being developed. These include hybrid products, which select variables from different sources including NWP, satellite, and in situ variables. Bias adjustments based on product differences (e.g. [78]), energy constraints (e.g. [64]) or fits to satellite (e.g. [40]) or in situ data (e.g. [64]) can be applied. Blended datasets, where multiple data sources are combined for each variable, can be in good agreement with climate quality in situ data (e.g. [79, 80 and 81]). However, biases in fluxes can result from mismatches of spatial and temporal scales or when data are combined with NWP products to which the same data have already been assimilated. Some blended and hybrid products suffer from changes in the observing system and those using operational products from changing NWP assimilation methods. These errors are serious for analysis of decadal variability and trends. Blended datasets reduce the often large differences between data sources.

Improvements in blended products will naturally arise as the quality of input data sources increases. Improvements in satellite shortwave and longwave radiation fields [60] and surface temperature and humidity [45] would be particularly beneficial. Characterization of all input data sources with uncertainty estimates should be a priority, and correlations between the errors in the input data sources must be determined. As for all flux datasets, better determination of spatial and temporal variability scales will give improved products. New buoys at high latitude and in the Indian Ocean will improve verification and tuning of blended datasets, improving products especially in data sparse regions.

Blended products are likely to produce the best quality flux datasets for many applications including for forcing ocean models and analysis of interannual variability. However it is also necessary to maintain single-source flux products, both for applications such as validation for which independence of data is crucial, and as a necessary step to understanding and improving the quality of the data used in blended products.

\subsection{Residual methods}

Surface fluxes may be deduced independently from surface flux parameterizations as residuals from assimilated observations of oceanic or atmospheric profiles [82]. Surface heat fluxes can be diagnosed from closure of the upper ocean heat balance [83 and 84]. Ocean state estimation offers a means to refine surface fluxes in order to make them more consistent with ocean observations [85, 86 and 87]. Assimilation of ocean data adds mesoscale structure to the fluxes that is not present in the original flux forcing fields [88], however progress is limited by an insufficient knowledge of the error characteristics of turbulent fluxes calculated from NWP products used for forcing, particularly at the high resolutions required [89], as well as by propagation of errors in the model parameterizations.

\section{THE NEED FOR NEW OBSERVATION}

Sustained high quality in situ observations of fluxrelated variables are needed where the present sampling is sparse or lacking, and especially at high latitudes, where variability is high.

The turbulent transport coefficients in existing bulk flux algorithms vary with wind speed and atmospheric stability (Fig. 5). Much less well understood is the influence of wave characteristics such as steepness, age, breaking, white-capping, direction of propagation relative to the wind and the presence or absence of swell. Other complicating factors are rainfall, surfactants, and the relationship of the interface temperature to the measured subsurface temperature. Measurements of these parameters under a full range of weather conditions are required to understand any effect on surface fluxes and for incorporation into new flux parameterizations. 
New sustained observation programs using direct flux observing technologies on more continuously operating platforms (buoys, weather ships, and research vessels) are needed to supplement research campaigns. A recent example is the instrumentation of a Norwegian Ocean
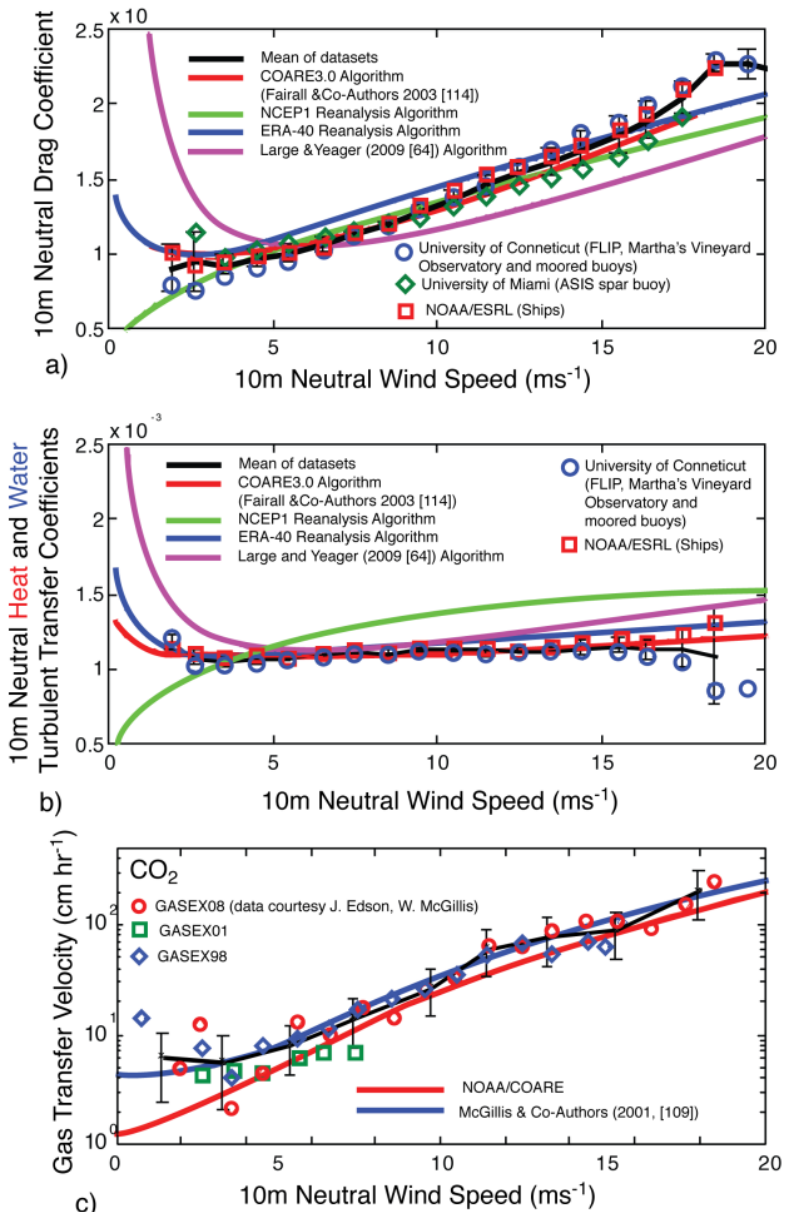

c)

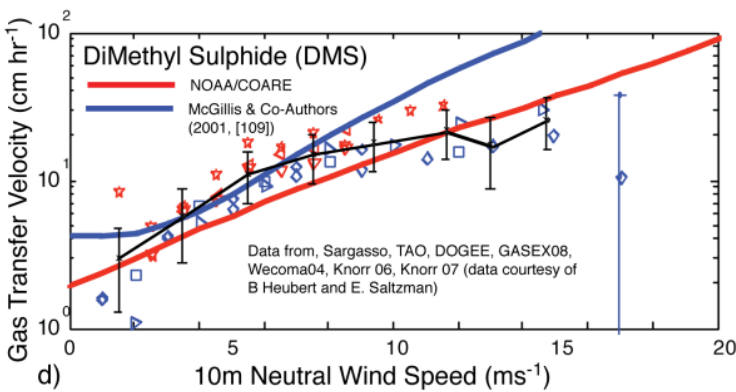

Figure 5: Flux transfer coefficients as a function of $10 \mathrm{~m}$ neutral wind speed; points are from direct (turbulence) observation, lines are parameterizations. a) drag coefficient (momentum); b) transfer coefficient from observations for heat (red squares) and water (blue circles), heat and water transfer coefficients are the same for the parameterizations shown; c) gas transfer velocity for $\mathrm{CO}_{2}$ on logarithmic scale; d) gas transfer velocity for DMS (dimethyl sulphide) (note change of log. scale).

Weather Ship (OWS) with an autonomous flux system [90], including measurement of whitecaps, directional wave spectra and sea-spray aerosol flux [91]. Measurements of whitecapping will aid development of algorithms for remote sensing of whitecaps [92], for use in new gas and aerosol flux parameterizations. As more power becomes available on buoy networks, direct covariance flux packages should be added.

The behavior of gas and aerosol fluxes at high winds is poorly known, with gas transfer velocities uncertain by about $100 \%$ for winds of $15 \mathrm{~ms}^{-1}$ [93]. Progress has been made in the parameterization of sea salt aerosol fluxes [94]. However, recent formulations converge to only about a factor of 3-5, and more measurements are required in a variety of different conditions. Opportunistic efforts taking advantage of $\mathrm{O}_{2}$ disequilibria arising from biological productivity [95], radon deficit methods or utilizing atmospheric ${ }^{14} \mathrm{C}$ excesses from bomb testing [96, 97 and 98] provide valuable information on air-sea gas exchange. Waterside tracer release techniques provide regional gas exchange estimates [99]. Large-scale information is obtained from upscaling field studies. Many more measurements of surface ocean and atmospheric $\mathrm{pCO}_{2}$ are needed [100] along with improved data management to facilitate the development of both new parameterizations and of high spatial resolution global $\mathrm{CO}_{2}$ air-sea flux products with realistic variability. Information on ocean biology and aerosols from satellites provides important information for gas exchange [101, 102 and 103].

Validation of open ocean satellite precipitation measurements uses comparisons with precipitation radars at coastal and island-based sites which are in turn calibrated against in situ rain gauges and disdrometers. However, as algorithm retrieval errors have a strong dependence on meteorological regime [104], ships equipped with credible precipitation instruments could provide important validation particularly with the Global Precipitation Measurement (GPM) constellation of satellites scheduled for launch in 2013. A renewed effort to develop and deploy improved accuracy shipboard rain gauges would benefit coupled model validation. Closure of the upper ocean heat and freshwater budgets from shipboard surveys has been shown to be feasible (e.g. [84]) and offers another possibility for space-borne sensor validation.

\section{TECHNOLOGY DEVELOPMENT AND IMPROVED OBSERVATIONS}

In situ sensors for the fluxes of energy, heat, water and salt were recently reviewed [28]. There is a continuing need to investigate the performance of existing sensors, for example calibration and comparability of radiometers remains a challenge, gas flux sensors are of marginal accuracy and reliability in open ocean conditions, and aerosol flux measurements are in their infancy. The development and introduction of new 
sensors, for example for $\mathrm{CO}_{2}$, ozone, $\mathrm{SO}_{2}$, and DMS concentration is a priority.

Increasing power availability on buoys will allow longterm deployments in harsher environments. More power will allow: aspiration of air temperature and humidity sensors, and radiometer bodies, to reduce solar heating errors; simultaneous operation of turbulent flux sensors with bulk meteorological systems; active leveling of radiometer mounts; and the use of heaters and de-icers to cope with ice and freezing sea spray.

Increased buoy power will also support routine deployments of infrared gas analyzers (for $\mathrm{CO}_{2}$ and $\mathrm{H}_{2} \mathrm{O}$ ), and, potentially, more advanced sensors using remote sensing or in situ analyzer methodologies. The coincident measurement of aerosol fluxes [105] and chemical and physical fluxes is needed to understand the role of the ocean in climate. The development of small-volume gas and aerosol flux sensors will allow deployment on moorings and drifters. Low-power, selfcontained flux sensor packages suitable for deployment on coastal weather and navigational buoys should be developed.

Humidity sensors suitable for long-term deployments do not have the required accuracy and measurements are affected by contaminants. SST is also problematic to measure: sensors are highly accurate but variations of temperature with depth, including the skin effect [42], mean that the representativeness of measurements is hard to determine due to ship and buoy motion and water flow past the hull. The development of processing systems for scans from ship navigation radars would provide cost-effective information on the directional wave spectrum [106] and perhaps precipitation.

Accurate measurements of precipitation at sea are vital. Optical disdrometers are expensive. Well-calibrated and properly installed funnel rain gauges can be effective but need developing to sample blown rain and should ideally be deployed alongside optical rain gauges. Costeffective rain radar technology for use on ships should be developed. Underwater acoustic sensors have shown some promise [107].

Work is needed to extend capabilities to extreme wind conditions. Here, the priority should be placed on the design of sensors capable of performance in environments with heavy spray loads. For instance, pressure-sphere anemometers [108], developed for landbased hurricane studies, should be modified for marine use.

Gas and aerosol flux sensors are still being developed. Currently sensors are marginal in terms of accuracy and robustness for the open ocean environment, however improvements are being made [109, 91 and 110].

Also important is the adoption of best practices for deploying sensors on ships and buoys [8]. High quality flux systems can be installed on vessels to understand the performance of the ship's existing sensors and guide improvements. Careful location of sensors, minimizing shadows, flow disturbance, and heat island effects remains essential. This may be facilitated by the development of routine methods to apply the results of computer modeling of wind flow distortion [37]. Data quality assurance and traceability of each sensor calibration to a standard is vital.

\section{DATA MANAGEMENT, STEWARDSHIP AND DISSEMINATION}

Surface flux and related datasets are obtained from a variety of platforms and methods and require data homogenization and scientific data stewardship (e.g. [111]). The flux measurement handbook [8] and the "Ten Climate Monitoring Principles" [112 and 113] guide flux data collection, documentation and management. International co-ordination is required to make flux data and products from a variety of methods and in various data formats easily available to a wide range of users. An integrated data management system could provide tools for the combination, viewing and analysis of data from different sources which can be downloaded in a choice of formats. Free and open data access and centralized data availability and cataloging are needed to provide wider access for applications including dataset evaluations and intercomparisons, and climate variability and predictability studies. The WCRP SURFA [65] and SAMOS [35] are examples of well-structured and open data management systems.

\section{RECOMMENDATIONS}

\subsection{The surface flux reference network under OceanSITES should be expanded}

Continued measurement of high quality mean meteorology, radiative fluxes and precipitation from the existing network. Current priorities for expansion are for more sites in subpolar and high latitude regions, where the sampling is sparse and variability is high, and also in regions with severe weather conditions. When technology allows observation capability should be extended to direct turbulent fluxes including gas and particle fluxes.

\subsection{The number of ships making high quality routine flux-related measurements should be increased}

Research vessels should routinely make high quality measurements of mean meteorology, radiative fluxes and precipitation and subsurface data. A subset should also measure direct fluxes, currents, directional wave spectra and other sea state information with a focus on regions of high variability and gaps in the OceanSITES network, such as high latitudes. Measurements should be expanded to selected commercial and other nonresearch vessels including those making subsurface and 
atmospheric soundings. An international inventory of planned Research Vessel deployments would help with coordination.

\subsection{VOS should be maintained and enhanced as a flux observation network}

The ability to maintain long-term in situ flux datasets requires the reinvigoration of the VOS scheme including an emphasis on providing the full ship report including visual observations of cloud, waves and weather, complete observation metadata and an increased number of regularly-reporting ships.

\subsection{Satellite flux observing system should be enhanced}

Priorities for satellite observations include improved retrievals of precipitation, near-surface air temperature and humidity and whitecap characteristics. Improved sampling is needed for vector winds, especially during high wind speed and rainy conditions, and also improved temporal coverage and higher spatial resolution for both passive and active microwave sensors especially in coastal regions.

\subsection{Flux observing system technologies should be improved}

Priorities for technology improvement include: Increased power and bandwidth on moorings; More robust and capable platforms with greater survivability for deployment in harsh environments; Improved gas and aerosol flux sensors including accurate and lowpower sensors for $\mathrm{CO}_{2}$, ozone, $\mathrm{SO}_{2}$ and DMS; Accurate and low-cost precipitation sensors; Improved mean humidity sensors for long-term deployments.

\subsection{The flux observing system should follow current best observational practice}

Best practice for flux measurement should be followed including careful sensor choice and siting, calibration to traceable standards and the maintenance of comprehensive metadata. Flux sensor systems should have a complete accuracy assessment as part of a quality assurance program.

\subsection{Flux parameterizations should be continually improved}

More direct flux measurements are needed to improve flux parameterizations, particularly under high and low wind conditions and for gases and particles under all conditions. Wave characteristics, including wave breaking, should be incorporated into parameterizations of turbulent fluxes of momentum, heat, water, gases and particles, and potentially sea surface albedo. Improved parameterizations of near-surface variations of ocean temperature with depth are needed. All flux parameterizations should be continuously revisited and regular review articles published.
8.8 A range of independent and well-characterised flux products is needed

A wide range of flux products is needed including from NWP/Reanalysis, satellite, in situ, and blended, each characterised by realistic estimates of uncertainty and error covariances. Improvements to dataset construction methods are needed including statistical techniques for homogenization of sampling and minimization of sampling errors. Accompanying metadata should characterize flux products so users can choose appropriately for their applications. Flux products including variables such as gas transfer velocity, air-sea biogeochemical and particle fluxes, and whitecap fraction should be developed. The validation and intercomparison of flux products is a priority.

8.9 Improved validation and parameterizations for NWP and reanalysis model fluxes is required

Observationalists, dataset developers and modelers should collaborate to validate and characterize fluxes from NWP and reanalysis using high quality flux data in a variety of regions, facilitated by the SURFA flux intercomparison project. Research is also needed to improve model flux parameterizations.

\subsection{Improved data stewardship and dissemination is needed}

Flux data and products should be made more easily available to both the research and operational communities and the benefits of aggregation of high quality flux data should be promoted. Improved metadata, including on dataset characteristics and suitability for particular applications should be produced, both by dataset producers and providers.

\section{REFERENCES}

1. Taylor, P.K. \& Co-Authors (2001). Surface fluxes and surface reference sites. In Koblinsky, C.J. and Smith, N.R. (eds.), Observing the Oceans in the 21st Century. ISBN 064270618 2, Melbourne, Australia, GODAE Project Office/Bureau of Meteorology, 177-197.

2. Taylor P. K., (2000). Intercomparison and validation of ocean-atmosphere energy flux fields - Final report of the Joint WCRP/SCOR Working Group on Air-Sea Fluxes. WCRP-112, WMO/TD-1036, 306 pp.

3. Gille, S. \& Co-Authors (2010). "Surface Fluxes in High Latitude Regions" in these proceedings (Annex), doi:10.5270/OceanObs09.

4. WCRP, (1989). WOCE Surface Flux Determinations - A strategy for in situ measurements. Working Group on in situ measurements for Fluxes WCRP-23 (WMO/TD No. 304), WMO, Geneva.

5. Webster, P.A., \& Lukas, R., (1992). The Coupled OceanAtmosphere Response Experiment. Bull. Am. Met. Soc., 73, 1377-1416. 
6. Weller, R.A., Bradley, E.F. \& Lukas, R. (2004). The interface or air-sea flux component of the TOGA Coupled Ocean-Atmosphere Response Experiment and its impact on subsequent air-sea interaction studies. J. Atmos. Oceanic Tech., 21, 223-257.

7. Fairall, C.W., Bradley, E.F., Rogers, D.P., Edson, J.B. \& Young, G.S., (1996). Bulk parameterization of air-sea fluxes for TOGA COARE. J. Geophys. Res., 101, 3747-3764.

8. Bradley, F. \& Fairall, C., (2007). A Guide to Making Climate Quality Meteorological and Flux Measurements at Sea. NOAA Technical Memorandum OAR PSD-311, NOAA/ESRL/PSD, Boulder, CO, 108 pp.

9. Berry, D.I. \& Kent, E.C. (2009). A new air-sea interaction gridded dataset from ICOADS with uncertainty estimates. Bull. Amer. Met. Soc., 90, 645-656. doi:10.1175/2008BAMS2639.1.

10. Wijffels, S., (2001). Ocean Freshwater Transport, in Ocean Circulation and Climate, G. Siedler, J. A Church and J. Gould, Eds., Academic Press, London, 475-488.

11. Béranger, K., Barnier, B., Gulev, S. \& Crepon, M., (2006). Comparing 20 years of precipitation estimates from different sources over the world ocean. Ocean Dyn., 56, 104-138. doi:10.1007/s10236-006-0065-2.

12. Lagerloef, G.S.E., (1988). Final Report of the First Workshop Salinity Sea Ice Working Group (SSIWG), La Jolla, CA, USA, 7-8 February 1998. http://www.esr.org/lagerloef/ssiwg/ssiwgrep1.v2.html

13. Schlax, M.G., Chelton, D.B. \& Freilich, M.H. (2001). Sampling errors in wind fields constructed from single and tandem scatterometer datasets. J. Atmos. Oceanic Tech., 18, 1014-1036.

14. Bony, S., Sud, Y., Lau, K.M., Susskind, J. \& Saha, S. (1997). Comparison and satellite assessment of NASA/DAO and NCEP-NCAR reanalyses over tropical ocean: Atmospheric hydrology and radiation. J. Climate, 10, 1441-1462.

15. Smith, S. R., Legler, D. M. \& Verzone, K. V. (2001). Quantifying uncertainties in NCEP reanalyses using high quality research vessel observations. J. Clim., 14, 4062-4072.

16. Milliff, R.F., Morzel, J., Chelton, D.B. \& Freilich, M.H. (2004). Wind stress curl and wind stress divergence biases from rain effects on QSCAT surface wind retrievals. J. Atmos. Oceanic Technol., 21, 1216-1231.

17. Lagerloef, G.S.E. \& Co-Authors (2003). El Nino Tropical Pacific Ocean surface current and temperature evolution in 2002 and outlook for early 2003. Geophys. Res. Lett., 30, 1514 doi:10.1029/2003GL017096.
18. \& Di Lorenzo E., (2009), Effects of small-scale features and local wind forcing on tracer dispersion and estimates of population connectivity in a regional scale circulation model, J. Geophys. Res., 114, C01012. doi:10.1029/2008JC004777.

19. Morey, S.L., Bourassa, M.A., Dukhovskoy, D.S. \& O'Brien, J. J. (2006). Modeling studies of the upper ocean response to a tropical storm. Ocean Dynamics, 56, 594-606. doi:10.1007/s10236-006-0085-y.

20. Cornillon, P. \& Park, K.A. (2001). Warm core ring velocities inferred from NSCAT. Geophys. Res. Lett., 28, 575-578.

21. Kelly, K.A., Dickinson, S., McPhaden, M.J. \& Johnson, C.G. (2001). Ocean currents evident in satellite wind data. Geophys. Res. Lett., 28, 2469-2472.

22. Chelton, D.B., Schlax, M.G., Freilich, M.H. \& Milliff, R., (2004). Satellite measurements reveal persistent smallscale features in ocean winds. Science, 303, 978-983.

23. Bourassa, M. A. (2006). Satellite-based observations of surface turbulent stress during severe weather, Atmosphere - Ocean Interactions, Vol. 2., ed., W. Perrie, Wessex Institute of Technology Press, Southampton, UK, 35 - 52 pp.

24. Lee, T., Wang, O., Tang, W.Q. \& Liu, W.T. (2008). Wind stress measurements from the QuikSCAT-SeaWinds scatterometer tandem mission and the impact on an ocean model. J. Geophys. Res., 113, C12019. doi:10.1029/2008JC004855.

25. Miller, R.F., Large, W.G., Morzel, J., Danabasoglu, O. \& Chin, T.M., (1999). Ocean general circulation model sensitivity to forcing from scatterometer winds. $J$. Geophys. Res., 104, 11337-11358.

26. Swail, V. \& Co-Authors (2010). "Storm Surge" in these proceedings (Vol. 2), doi:10.5270/OceanObs09.cwp.88.

27. Bindoff, N.L. \& Co-Authors (2007). Observations: Oceanic Climate Change and Sea Level. In: Climate Change 2007: The Physical Science Basis. Contribution of Working Group I to the Fourth Assessment Report of the Intergovernmental Panel on Climate Change Cambridge University Press, Cambridge, United Kingdom and New York, NY, USA.

28. Weller, R.A. \& Co-Authors (2008). Sensors for physical fluxes at the sea surface: energy, heat, water, salt. Ocean Science, 4, 247-263. doi:10.5194/os-4-247-2008.

29. Send, U. \& Co-Authors (2010). "A Global Boundary Current Circulation Observing Network" in these proceedings (Vol. 2), doi:10.5270/OceanObs09.cwp.78. 
30. Hayes, S., Mangum, L., Picaut, J., Sumi, A. \& Takeuchi, K., (1991). TOGA-TAO: A moored array for real-time measurements in the tropical Pacific Ocean. $J$. Geophys. Res., 72, 339-347.

31. McPhaden M.J. \& Co-Authors (2009). RAMA: The Research Moored Array for African-Asian-Australian Monsoon Analysis and Prediction. Bull. Am. Met. Soc., 90, 459-480. doi:10.1175/2008BAMS2608.1.

32. Bourlès, B. \& Co-Authors (2008). The Pirata Program: History, accomplishments, and future directions. Bull. Amer. Meteor. Soc., 89, 1111-1125. doi:10.1175/2008BAMS2462.1.

33. Kent, E. \& Co-Authors (2010). "The Voluntary Observing Ship (VOS) Scheme" in these proceedings (Vol. 2), doi:10.5270/OceanObs09.cwp.48.

34. Kent, E.C., Berry, D.I., Woodruff S.D. \& Taylor, P. K. (2006). Voluntary Observing Ships: A Vital Marine Observing System in Decline, CLIVAR Exchanges, 38, 20-21 (figs page 15), July 2006.

35. Smith, S. \& Co-Authors (2010). "The Data Management System for the Shipboard Automated Meteorological and Oceanographic System (SAMOS) Initiative" in these proceedings (Vol. 2), doi:10.5270/OceanObs09.cwp.83.

36. Berry, D.I., Kent, E.C. \& Taylor, P.K., (2004). An analytical model of heating errors in marine air temperatures from ships. J. Atmos. Oceanic Tech., 21, 1198-1215.

37. Yelland, M.J., Moat, B.I., Pascal, R.W. \& Berry, D.I. (2002). CFD model estimates of the airflow distribution over research ships and the impact on momentum flux measurements. J. Atmos. Oceanic Tech., 19, 1477-1499.

38. Moat, B. I., Yelland, M.J., Pascal, R.W. \& Molland, A.F. (2005). An overview of the airflow distortion at anemometer sites on ships. Int. J. Climatol., 25, 9971006. doi:10.1002/joc. 1177 .

39. Andersson, A. \& Co-Authors, (2007). Hamburg Ocean Atmosphere Parameters and Fluxes from Satellite Data - HOAPS-3 - twice daily composite., electronic publication, World Data Center for Climate, doi:10.1594/WDCC/HOAPS3_DAILY.

40. Bentamy, A. \& Co-Authors (2003). Satellite estimates of wind speed and latent heat flux over the global oceans, J. Climate, 16, 637 - 656.

41. Jackson, D.L., Wick, G.A. \& Bates, J.J. (2006). Nearsurface retrieval of air temperature and specific humidity using multisensor microwave satellite observations. J. Geophys. Res., 111, D10306, doi:10.1029/2005JD006431.

42. Donlon, C. \& Co-Authors (2010). "Successes and Challenges for the Modern Sea Surface Temperature Observing System" in these proceedings (Vol. 2), doi:10.5270/OceanObs09.cwp.24.
43. Bourassa, M. \& Co-Authors (2010). "Remotely Sensed Winds and Wind Stresses for Marine Forecasting and Ocean Modeling" in these proceedings (Vol. 2), doi:10.5270/OceanObs09.cwp.08.

44. Roberts, J.B., Clayson, C.A., Robertson, F.R. \& Jackson, D. (2010). Predicting near-surface characteristics from SSM/I using neural networks with a first guess approach. J. Geophys. Res., 115, D19113. doi:10.1029/2009JD013099.

45. Shi, L. \& Zhang, H.-M. (2009). Sea surface air temperature and humidity retrievals based on AMSU measurements. 16th Conference on Satellite Meteorology and Oceanography (http://ams.confex.com/ams/89annual/techprogram/pa per_149689.htm)

46. Ebert, E.E. \& Manton, M.J., (1998). Performance of satellite rainfall estimation algorithms during TOGA COARE., J. Atmos. Sci., 55, 1537-1557.

47. Stephens, G.L., \& Kummerow, C.D., (2007). The remote sensing of clouds and precipitation from space: A review. J. Atmos. Sci., 64, 3742-3765. doi:10.1175/2006JAS2375.1.

48. Woodruff, S.D., Diaz, H.F., Elms, J.D. \& Worley, S J. (1998). COADS Release 2 data and metadata enhancements for improvements of marine surface flux fields. Phys. Chem. Earth, 23, 517-526.

49. Worley, S.J., Woodruff, S.D., Reynolds, R.W., Lubker, S.J. \& Lott, N. (2005). ICOADS Release 2.1 data and products. Int. J. Climatol., 25, 823-842. doi:10.1002/joc.1166.

50. Worley, S. \& Co-Authors (2010). "The Role of the International Comprehensive Ocean-Atmosphere Data Set in the Sustained Ocean Observing System" in these proceedings (Vol. 2), doi:10.5270/OceanObs09.cwp.94.

51. Grist, J.P. \& Josey, S.A. (2003). Inverse analysis adjustment of the SOC air-sea flux climatology using ocean heat transport constraints. J. Climate, 16, 32743295 .

52. Chou, S.-H., Nelkin, E., Ardizzone, J., Atlas, R. \& Shie, C.-L, (2003). Surface turbulent heat and momentum fluxes over global oceans based on the Goddard satellite retrievals, version 2 (GSSTF2). J. Climate, 16, 3256-3273.

53. Kubota, M. \& Tomita, H., (2008). The Present State of the J-OFURO Air-Sea Interaction Data Product, FluxNews, 4, 13-15.

54. Clayson, C.A. \& Co-Authors (2011). Results of the SeaFlux Intercomparison Project. Bull. Amer. Meteorol. Soc., submitted.

55.Zhang, Y.-C., Rossow, W.B. Lacis, A.A. Oinas, V. \& Mishchenko, M.I. (2004). Calculation of radiative fluxes from the surface to top of atmosphere based on ISCCP and other global data sets: Refinements of the radiative transfer model and the input data. $J$. Geophys. Res., 109, D19105. doi:10.1029/2003JD004457. 
56. Ghate, V., Albrecht, B.A., Fairall, C.W. \& Weller, R.A., (2009). Cloud fraction climatology and its indicators in South-East Pacific Ocean. J. Clim., 20, 5527-5540. doi:10.1175/2009JCLI2961.1.

57. Lohmann, S, Schillings, C., Mayer, B. \& Meyer, R. (2006). Long-term variability of solar direct and global radiation derived from ISCCP data and comparison with reanalysis data. Solar Energy, 80, 1390-1401. doi:10.1016/j.solener.2006.03.004.

58. Cronin, M.F., Bond, N., Fairall, C.W. \& Weller, R.A. (2006). Surface cloud forcing in the Eastern Tropical Pacific. J. Clim., 19, 392-409.

59. Kato, S, Rose, F.G., Rutan, D.A. \& Charlock, R.P., (2008). Cloud effects on the meridional atmospheric energy budget estimated from Clouds and the Earth's Radiant Energy System (CERES) data. J. Clim., 21, 42234241. doi:10.1175/2008JCLI1982.1.

60. Pinker, R.T., Wang, H. \& Grodsky, S.A. (2009). How good are ocean buoy observations of radiative fluxes? Geophys. Res. Lett., 36, L10811. doi:10.1029/2009GL037840.

61. Xie, P., \& Arkin, P.A. (1996). Analyses of global monthly precipitation using gauge observations, satellite estimates, and numerical model predictions. J Clim., 9 , 840-858.

62. Adler, R.F., \& Co-Authors (2003). The Version 2 Global Precipitation Climatology Project (GPCP) Monthly Precipitation Analysis (1979-Present). $J$. Hydrometeor., 4, 1147-1167.

63. Joyce, R.J., Janowiak, J.E., Arkin, P.A. \& Xie, P. (2004). CMORPH: A method that produces global precipitation estimates from passive microwave and infrared data at high spatial and temporal resolution. $J$. Hydromet., 5, 487-503.

64. Large, W., \& Yeager, S., (2009). The global climatology of an interannually varying air-sea flux data set. Clim. Dynamics, 33, 341-364. doi:10.1007/s00382-008-0441-3.

65. Fairall, C.W. \& Miller, M., (2007). Report on the joint WGSF - WGNE meeting on SURFA. FluxNews, Issue 3, January 2007.

66. Kalnay, E. \& Co-Authors (1996). The NCEP/NCAR 40Year Reanalysis Project. Bull. Amer. Meteor. Soc., 77, 437-471.

67. Kanamitsu, M. \& Co-Authors (2002). NCEP-DOE AMIPII Reanalysis (R-2). Bull. Amer. Meteor. Soc., 83, 1631-1643.

68. Uppala, S. M. \& Co-Authors (2005). The ERA-40 reanalysis. Quart. J. R. Meteorol. Soc., 131, 2961-3012. doi:10.1256/qj.04.176.

69. Onogi, K. \& Co-Authors (2007). The JRA-25 Reanalysis. J. Meteorol. Soc. Japan, 85, 369-432.

70. Sterl, A., (2004). On the (In)Homogeneity of reanalysis products. J. Clim., 17, 3866-3873.
71. Gulev, S.K., Jung, T. \& Ruprecht, E. (2007). Estimation of the impact of sampling errors in the VOS observations on air-sea fluxes. Part II. Impact on trends and interannual variability. J. Climate, $\mathbf{2 0}$, doi:10.1175/JCLI4008.1.

72. Quartly, G.D., Kyte, E.A., Srokosz M.A. \& Tsimplis, M.N. (2007). An intercomparison of global oceanic precipitation climatologies, J. Geophys. Res., 112, D10121. doi:10.1029/2006JD007810.

73. Kyte, E.A., Quartly, G.D., Srokosz M.A. \& Tsimplis, M.N. (2006). Interannual variations in precipitation: The effect of the North Atlantic and Southern Oscillations as seen in a satellite precipitation data set and in models, J. Geophys. Res., 111, D24113. doi:101029/2006JD007138.

74. Compo, G.P., Whitaker, J.S. \& Sardeshmukh, P.D. (2006). Feasibility of a 100-year reanalysis using only surface pressure data. Bull. Amer. Met. Soc., 87, 175-190. doi:10.1175/BAMS-87-2-175.

75. Trenberth, K. \& Co-Authors (2010). "Atmospheric Reanalyses: A Major Resource for Ocean Product Development and Modeling" in these proceedings (Vol. 2), doi:10.5270/OceanObs09.cwp.90.

76. Jiang, C., Cronin, M.F., Kelly, K.A. \& Thompson, L., (2005). Evaluation of a hybrid satellite- and NWPbased turbulent heat flux product using the Tropical Atmosphere-Ocean (TAO) buoys. J. Geophys. Res., 110, C09007. doi:10.1029/2004JC002824.

77. Yu, L., \& Weller, R.A. (2007). Objectively analyzed airsea flux fields for the global ice-free oceans (19812005). Bull. Amer. Met. Soc., 88, 527-539. doi:10.1175/BAMS-88-4-527.

78. Zhang, H-M. \& Co-Authors (2009). An integrated global ocean observing system for sea surface temperature using satellites and in situ data. Bull. Amer. Meteorol. Soc., 90, 31-28. doi:10.1175/2008BAMS2577.1.

79. Yu, L., Jin, X. \& Weller, R. A. (2007). Annual, seasonal, and interannual variability of air-sea heat fluxes in the Indian Ocean. J. Clim., 20, 3190-3209. doi:10.1175/JCLI4163.1.

80. Yu, L., Weller, R.A. \& Sun, B. (2004a). Improving latent and sensible heat flux estimates for the Atlantic Ocean (1988-1999) by a synthesis approach. J. Clim., 17, 373-393.

81. Yu, L., Weller, R.A. \& Sun, B. (2004b). Mean and variability of the WHOI daily latent and sensible heat fluxes at in situ flux measurement sites in the Atlantic Ocean. J. Clim., 17, 2096-2118.

82. Trenberth, K.E., Caron, J.M. \& Stepaniak, D.P. (2001). The atmospheric energy budget and implications for surface fluxes and ocean heat transports. Climate Dyn., 17, 259-276.

83. Dong, S., Gille, S. T. \& Sprintall, J., (2007). An assessment of the Southern Ocean mixed-layer heat budget, J. Clim., 20, 4425-4442. doi:10.1029/2006JC004051. 
84. Wijesekera, H.W., \& Co-Authors (2005). Upper ocean heat and freshwater budgets in the eastern Pacific warm pool. J. Geophys. Res., 110, C08004. doi:10.1029/2004JC002511.

85. Wunsch, C. and P. Heimbach, 2007: Practical global ocean state estimation. Physica D, 230(1-2), pp. 197-208, doi:10.1016/j.physd.2006.09.040.

86. Stammer, D. \& Co-Authors (2004). Estimating air-sea fluxes of heat, freshwater and momentum through global ocean data assimilation. J. Geophys. Res., 109, C05023. doi:10.1029/2003JC002082.

87. Skachko S., Brankart, J.-M., Castruccio, F. Brasseur, P. \& Verron, J. (2009). Improved turbulent air-sea flux bulk parameters for the control of the ocean mixed layer: A sequential data assimilation approach. J. Atmos. Oceanic Tech., 26, 538-555. doi:10.1175/2008JTECHO603.1.

88. Mazloff, M., Heimbach, P. \& Wunsch, C. (2010). An eddy permitting Southern Ocean state estimate. 40, 880899. doi:10.1175/2009JPO4236.1.

89. Large W., (2006). Surface fluxes for practitioners of global ocean data assimilation. E. P. Chassignet \& J. Verron (eds.), Ocean Weather Forecasting, 229-270. Springer. Printed in the Netherlands.

90. Yelland, M.J., Pascal, R.W., Taylor P.K. \& Moat, B.I. (2009). AutoFlux: an autonomous system for the direct measurement of the air-sea fluxes of $\mathrm{CO}_{2}$, heat and momentum. J. Operational Oceanog., 2, 15-23.

91. Hill M.K. \& Co-Authors (2008). A Compact Lightweight Aerosol Spectrometer Probe (CLASP). J. Atmos. Oceanic Technol., 25, 1996-2006. doi:10.1175/2008JTECHA1051.1.

92. Anguelova, M. D. \& Webster, F. (2006). Whitecap coverage from satellite measurements: A first step toward modelling the variability of oceanic whitecaps. J. Geophys. Res., 111, C03017. doi:10.1029/2005JC003158.

93. Wanninkhof, R., Asher, W.E., Ho, D.T. Sweeney, C. \& McGillis, W.R. (2009). Advances in quantifying airsea gas exchange and environmental forcing. Annu. Rev. Mar. Sci., 1, 213-44. doi:10.1146/annurev.marine.010908.163742.

94. O'Dowd, C.D. \& de Leeuw, G. (2007). Marine aerosol production: A review of the current knowledge. Phil. Trans. R. Soc. A., 365, 1753-1774. doi:10.1098/rsta.2007.2043.

95. Redfield, A.C., (1948). The exchange of oxygen across the sea surface. J. Mar. Res., 7, 347-61.

96. Broecker, W.S., Peng, T.-H., Ostlund, G. \& Stuiver, M. (1985). The distribution of bomb radiocarbon in the ocean. J. Geophys. Res., 99, 6953-6970.

97. Broecker, W.S., Sutherland, S., Smethie, W., Peng, T.-H. \& Ostlund, G., (1995). Oceanic radiocarbon: separation of the natural and bomb components. Glob. Biogeochem. Cycles, 9, 263-88.
98. Sweeney, C., et al., (2007). Constraining global air-sea gas exchange for $\mathrm{CO}_{2}$ with recent bomb $14 \mathrm{C}$ measurements. Glob. Biogeochem. Cycles, 21, GB2015. doi:10.1029/2006GB002784.

99. Ho, D.T., Law, C.S., Smith, M.J., Schlosser, P., Harvey, M. \& Hill, P., (2006). Measurements of air-sea gas exchange at high wind speeds in the Southern Ocean: implications for global parameterizations. Geophys. Res. Lett., 33, L16611. doi:10.1029/2006GL026817.

100. Monteiro, P. \& Co-Authors (2010). "A Global Sea Surface Carbon Observing System: Assessment of Changing Sea Surface CO2 and Air-Sea CO2 Fluxes" in these proceedings (Vol. 2), doi:10.5270/OceanObs09.cwp.64.

101. Bennington, V., McKinley, G. A. Dutkiewicz, S. \& Ullman D., (2009). What does chlorophyll variability tell us about export and air-sea $\mathrm{CO}_{2}$ flux variability in the North Atlantic?, Global Biogeochem. Cycles, 23, GB3002. doi:10.1029/2008GB003241.

102. Chierici, M., Olsen, A., Johannessen, T., Trinañes, J. \& Wanninkhof, R., 2009. Algorithms to estimate the carbon dioxide uptake in the northern North Atlantic using ship-observations, satellite and ocean analysis data. Deep-Sea Research II, 56, 630-639. doi:10.1016/j.dsr2.2008.12.014.

103. Doney, S.C., \& Co-Authors (2009). Mechanisms governing interannual variability in upper-ocean inorganic carbon system and air-sea $\mathrm{CO}_{2}$ fluxes: physical climate and atmospheric dust, Deep-Sea Res. II, 56, 640-655. doi:10.1016/j.dsr2.2008.12.006.

104. Petersen, W.A., \& Schwaller, M.R. (2008). GPM Ground Validation: Science Implementation Plan - Draft July 10 2008, NASA.

105. Norris, S.J. \& Co-Authors (2008). Eddy covariance measurements of sea spray particles over the Atlantic Ocean. Atmos. Chem. Phys., 8, 555-563. doi:10.5194/acp-8-555-2008.

106. Nieto Borge, J.C., Rodriguez, G.R., Hessner, K. \& Gonzalez, P.I. (2004). Inversion of marine radar images for surface wave analysis. J. Atmos. Oceanic Tech., 21, 1291-1300.

107. Ma, B.B. \& Nystuen, J.A., (2005). Passive acoustic detection and measurement of rainfall at sea. J. Atmos. and Oceanic Tech. 22 1225-1248.

108. Eckman, R.M., Dobosy, R.J., Auble, D.L., Strong, T.W. \& Crawford, T.L., (2007). A pressure-sphere anemometer for measuring turbulence and fluxes in hurricanes. J. Atmos. Oceanic Technol., 24, 994-1007. doi: 10.1175/JTECH2025.1.

109. McGillis, W.R. \& Co-Authors (2001). Carbon dioxide flux techniques performed during GasEx98. J. Marine Chem., 75, 267-280.

110. Prytherch J. \& Co-Authors, (2009). Direct measurements of the $\mathrm{CO}_{2}$ flux over the ocean: development of a novel method. Geophys. Res. Lett., 37, L09601. doi:10.1029/2009GL041482. 
111. NRC (US National Research Council), (2005). Review of NOAA's Plan for the Scientific Stewardship Program. National Academy Press, USA, 38pp.

112. Karl, T.R. \& Co-Authors (1995). Critical issues for longterm climate monitoring. Climatic Change, 31, 185221.

113. NRC (US National Research Council) (1999). Adequacy of Climate Observing Systems. National Academy Press, USA, 51pp.

114. Fairall, C.W., Bradley, E.F., Hare, J.E., Grachev, A.A. \& Edson, J.B., (2003). Bulk parameterization of air-sea fluxes: Updates and verification for the COARE algorithm. J. Clim., 16, 571-591. 